\title{
Sensitivity to ionising radiation of lymphocytes from Huntington's chorea patients compared to controls
}

\author{
DERMOT MCGOVERN* AND TESSA WEBB $\dagger$ \\ From * All Saints Hospital, Lodge Road, Birmingham, B18 5SD, and \\ $\dagger$ Department of Clinical Genetics, Infant Development Unit, The Maternity Hospital, Birmingham B15 2TG
}

SUMMARY Blood samples were collected from 22 patients with Huntington's chorea and from 22 matched controls. Lymphocytes were separated from aliquots of each sample and cultures set up both from these and from further aliquots of whole blood. After 24 hours, half of each culture was subjected to $X$ irradiation. Seventy-two hours later the percentages of live lymphocytes were estimated for each half of every culture and the viability ratio calculated for each sample. The lymphocytes derived from the patients with Huntington's chorea were found to be more susceptible to $\mathrm{X}$ irradiation than were the lymphocytes derived from controls. This was true both for whole blood and separated lymphocyte cultures. This susceptibility was found not to be the result of the main types of medication received by the patients. The small differences between viability ratios from patients and controls and the degree of overlap makes this test unsuitable for the prediction of asymptomatic carriers of the Huntington's chorea gene.

Huntington's chorea $(\mathrm{HC})$ is a presenile dementia characterised by progressive mental deterioration and choreiform movements. The condition is of autosomal dominant inheritance with complete penetrance and an average age of onset of 44 years. ${ }^{1}$ As most cases first show symptoms between 25 and 55 years of age, the diagnosis is usually made after the most fertile years by which time the gene may have been passed on to the next generation.

From its histopathological appearance the disease is classified as one of the neuronal degenerations. ${ }^{2}$ This led Moshell et $a l^{3}$ to study cells from HC patients in case Huntington's chorea resembled other diseases with neuronal degeneration in which defects in DNA repair occur. Ataxia telangiectasia (AT) and some complementation groups of xeroderma pigmentosum with nervous system involvement have similar neuronal degeneration. These conditions are both rare autosomal recessive diseases characterised by defects in DNA repair after exposure to UV light $^{4}$ (xeroderma pigmentosum) or ionising radiation (ataxia telangiectasia). ${ }^{5}$ In the above studies, ${ }^{3}$ lymphoblastoid cell lines from four HC patients were subjected to doses of $x$-rays or UV light and the cell viability compared with that of similarly treated lines from control patients. The lymphoblastoid lines from HC patients were found

Received for publication 13 July 1981 to be abnormally sensitive to $X$ irradiation. Of five lines derived from family members at risk, three showed normal radiosensitivity and two were hypersensitive, indicating the possibility of presymptomatic diagnosis.

If cells from Huntington's chorea patients do respond differently to irradiation compared to those from controls, this could possibly lead to a way of detecting patients before they develop symptoms.

Several studies have concentrated on the possibility of presymptomatic diagnosis, the most recent developments being reviewed by Propert. ${ }^{6}$ The general approach has been to detect a possible difference between $\mathrm{HC}$ patients and healthy controls and then to determine whether it is shared by a proportion of the relatives at risk. The significance of any diagnosis can only be determined by long term follow-up.

Such studies have included those on the properties of red cell membranes, ${ }^{7}$ on the growth potential of skin fibroblasts, ${ }^{8}$ and on hypersensitivity of $\mathrm{HC}$ lymphocytes to $\mathrm{HC}$ brain tissue. ${ }^{9}$

Studies on the patients themselves include computed tomography, ${ }^{10}$ and the estimation of neurotransmitters such as $\gamma$-aminobutyric acid in cerebrospinal fluid.11 Two series of investigative studies attempted to predict which subjects would develop HC and then followed up these patients 
several years later. Patterson et al ${ }^{12}$ divided their patients at risk on the basis of electroencephalography, but a follow-up study performed 18 to 20 years later concluded that this test had little or no predictive value. ${ }^{13}$

Klawans et al ${ }^{14}$ administered L-dopa to patients at risk in order to induce choreic movements in those who carried the HC gene. This proved to be much more reliable as a predictive test for $\mathrm{HC}$, but the induction of choreic movements in positive responders has grave psychological side effects.

Despite the variation in tissues and properties investigated none of these studies has so far fulfilled the function of a predictive test for Huntington's chorea. Some of them have not yet been applied to patients at risk and others are either invasive or distressing or both. The search for genetic markers for HC in linkage studies has been similarly unsuccessful. ${ }^{15} 16$

Preliminary studies with skin fibroblast strains derived from HC patients suggested that they were also sensitive to ionising radiation, ${ }^{17}$ but a later report with further strains derived from both patients and relatives at risk ${ }^{\mathbf{1 8}}$ did not confirm this finding.

In all these studies ${ }^{317} 18$ the numbers were small and there was no indication that possible variables such as age or medication were considered. The present study seeks to improve on all these factors, and lymphocytes have been studied rather than lymphoblastoid lines. As for Huntington's chorea the latter are technically difficult and time-consuming to produce, it would be of considerable advantage if hypersensitivity to ionising radiation could be demonstrated in lymphocytes, which are far more readily available. Variation in the susceptibility of cells from subjects with different diseases to the production of lymphoblastoid lines is well documented.

Two hypotheses were tested: (1) that the lymphocytes of patients with $\mathrm{HC}$ are more sensitive to $x$-rays than those of healthy controls; and (2) that a proportion of their relatives, at risk for developing the condition, share this abnormality.

\section{Materials and methods}

Twenty-two randomly ascertained patients with HC were studied. They were all examined by one of the authors and to ensure diagnostic accuracy and homogeneity all fulfilled the following criteria.

(1) A firm diagnosis of $\mathrm{HC}$ had been made by either a consultant psychiatrist or neurologist (usually both).

(2) At least one first degree relative had previously been diagnosed as suffering from HC (in all but one case this was a parent).
(3) The presence of choreiform movements was demonstrated.

(4) The presence of a degree of dementia was demonstrated (the dementia was usually quite profound but in one early case was evidenced only by a decreased ability to concentrate).

As a group they represented a chronic population in that only six were still resident in the community.

Healthy, drug-free, age matched (where possible) controls were paired with each patient, each pair being analysed in the same experiment to control for any variation between experiments.

The problem of controlling for patient medication was more difficult because patients were being treated with more than $\mathbf{3 0}$ different drugs in various combinations with an average of nearly four each. One patient took nine different drugs. It was decided to control for the commonest groups used, oral phenothiazines and benzodiazepines. Patients with functional mental illnesses were chosen as controls; five had been on benzodiazepines for at least 6 months and six had been treated with phenothiazines for at least a year.

Eighteen first degree relatives at risk for developing the condition were also tested.

\section{EXPERIMENTAL TECHNIQUE}

On the day of collection, the blood samples were treated by two methods.

(1) Whole blood $(0.5 \mathrm{ml})$ was added to RPM1 1640 tissue culture medium $(4.5 \mathrm{ml})$ containing $10 \%$ fetal calf serum and phytohaemagglutinin $(0.05 \mathrm{ml})$. These cultures were then maintained at $37^{\circ} \mathrm{C}$.

(2) Lymphocytes were separated from the blood samples $(2.5 \mathrm{ml})$ by employing standard lymphocyte separation medium (Flow Laboratories Ltd). The lymphocyte layer visible after centrifugation was removed aseptically, washed in serum-free medium, and added to whole tissue culture medium exactly as described above.

After 24 hours' incubation at $37^{\circ} \mathrm{C}$ all the cultures were divided equally in half. One half was subjected to $X$ irradiation using $245 \mathrm{kV} x$-rays with $0.1 \mathrm{~mm}$ $\mathrm{Cu}$ and $1.0 \mathrm{~mm} \mathrm{~A} 1$ filtration, dose rate 0.57 rads/ $\mathrm{sec}^{-1}$.

After irradiation fresh tissue culture medium $(2.5 \mathrm{ml})$ was added to both irradiated and control cultures and they were all reincubated for a further 72 hours at $37^{\circ} \mathrm{C}$.

The total numbers of cells both live and dead were then determined in a haemocytometer after staining with vital stain Trypan blue. Aliquots of the separated lymphocyte cultures could be determined directly after concentration by centrifugation, but aliquots of the whole blood cultures were first 
treated with a hypotonic solution of ammonium chloride in order to lyse the red cells. Numbers of live and dead cells present were recorded for each sample, both control and irradiated.

Viability ratios were determined for each blood sample by first calculating the percentage of live cells present in both the irradiated and the control half of each culture. These percentages were then used to calculate a viability ratio.

Viability ratio $=$ percentage of live cells in irradiated culture/percentage of live cells in non-irradiated culture.

\section{Results}

Table 1 documents each of 22 patients with Huntington's chorea who participated in the study, along with 22 matched controls. The table compares the

TABLE 1 Patients and controls

\begin{tabular}{|c|c|c|c|c|}
\hline $\begin{array}{l}\text { Patients with } \\
\text { Huntington's } \\
\text { chorea }\end{array}$ & Age & Drug regimen & $\begin{array}{l}\text { Control } \\
\text { patient }\end{array}$ & Age \\
\hline JR & 51 & Haloperidol & $\mathbf{A R}$ & 49 \\
\hline DR & 50 & $\begin{array}{l}\text { Indocid, Anafranil, } \\
\text { Moduretic, Welldorm }\end{array}$ & PB & 37 \\
\hline MB & 50 & $\begin{array}{l}\text { Pericyazine, Kemadrin, } \\
\text { Largactil, Amitryptiline, } \\
\text { Folic acid }\end{array}$ & SH & 30 \\
\hline DC & 50 & $\begin{array}{l}\text { Chlorpromazine, Perphena- } \\
\text { zine, Dartalan, Fluphenazine, } \\
\text { Glutethimide }\end{array}$ & $\mathbf{R M}$ & 27 \\
\hline $\mathbf{A H}$ & 37 & $\begin{array}{l}\text { Tetrabenazine, Benzhexol, } \\
\text { Chlormethiazole, Salbutamol }\end{array}$ & RH & 32 \\
\hline RG & 21 & $\begin{array}{l}\text { Diazepam, Chlorpromazine, } \\
\text { Ativan, Orphenadine, } \\
\text { Folic acid, Nitrazepam, } \\
\text { Seconal, Chlormethiazole, } \\
\text { Tetrabenazine }\end{array}$ & MG & 25 \\
\hline MC & 20 & Fluphenazine, Disipal & JC & 23 \\
\hline MM & 37 & $\begin{array}{l}\text { Redeptin, Trimipramine, } \\
\text { Nitrazepam }\end{array}$ & TK & 40 \\
\hline AC & 27 & $\begin{array}{l}\text { Nitoman, Haloperidol, } \\
\text { Chlorpromazine, } \\
\text { Temazepam, Procyclidine }\end{array}$ & SD & 28 \\
\hline DM & 30 & $\begin{array}{l}\text { Fentazine, Valium, } \\
\text { Tegretol, Diazepam, } \\
\text { Procyclidine }\end{array}$ & DM & 31 \\
\hline JE & 40 & $\begin{array}{l}\text { Chlorpromazine, Dartalan, } \\
\text { Nitoman, Ascorbic acid, } \\
\text { Ventolin }\end{array}$ & KK & 40 \\
\hline GC & 47 & Haloperidol, Surmontil & PS & 40 \\
\hline NS & 53 & $\begin{array}{l}\text { Haloperidol, Procyclidine, } \\
\text { Diazepam }\end{array}$ & JG & 52 \\
\hline MW & 37 & Thiopropazate, Melleril & SS & 40 \\
\hline LH & 62 & $\begin{array}{l}\text { Chlorpromazine, } \\
\text { Tetrabenazine }\end{array}$ & AA & 62 \\
\hline $\mathbf{J L}$ & 50 & $\begin{array}{l}\text { Chlorpromazine, } \\
\text { Tetrabenazine }\end{array}$ & MC & 50 \\
\hline MA & 47 & $\begin{array}{l}\text { Diazepam, Melleril, } \\
\text { Dartalan }\end{array}$ & JR & 49 \\
\hline EO & 58 & Thioridazine & JT & 54 \\
\hline EB & 42 & $\begin{array}{l}\text { Pimozide, Nitrazepam, } \\
\text { Oestrogen, Melleril }\end{array}$ & MB & 34 \\
\hline PD & 68 & $\begin{array}{l}\text { Largactil, Disipal, } \\
\text { Folic acid }\end{array}$ & JW & 52 \\
\hline $\begin{array}{l}\text { WD } \\
\text { JF }\end{array}$ & $\begin{array}{l}46 \\
42\end{array}$ & $\begin{array}{l}\text { Pimozide, Nitrazepam } \\
\text { Isoniazid, Pyridoxine }\end{array}$ & $\begin{array}{l}\text { KR } \\
\text { SB }\end{array}$ & $\begin{array}{l}50 \\
34\end{array}$ \\
\hline
\end{tabular}

ages of the patients with those of the controls and lists the medication received. In 18 of 22 pairs, the age matching of controls to patients was within 8 years, the average age of the patients being 43.9 years and that of the controls 40.0 years.

Fig 1 shows the viability ratios for the $22 \mathrm{HC}$ patients and their matched controls. The pairs were analysed in the same experiment and the results shown are for whole blood samples. Fig 2 shows the viability ratios of separated lymphocytes derived from the same series of patients and matched controls. Differences between the groups of HC patients and controls are clear visually, although there is overlap. The means and standard deviations are given in the figures.

Fig 3 shows the viability ratios for a series of patients suffering from functional mental illnesses also on oral phenothiazines or benzodiazepines. Ratios calculated from whole blood and separated lymphocyte cultures are shown together in the figure. The difference between this group and the HC patients shown in fig 1 is again clear, suggesting

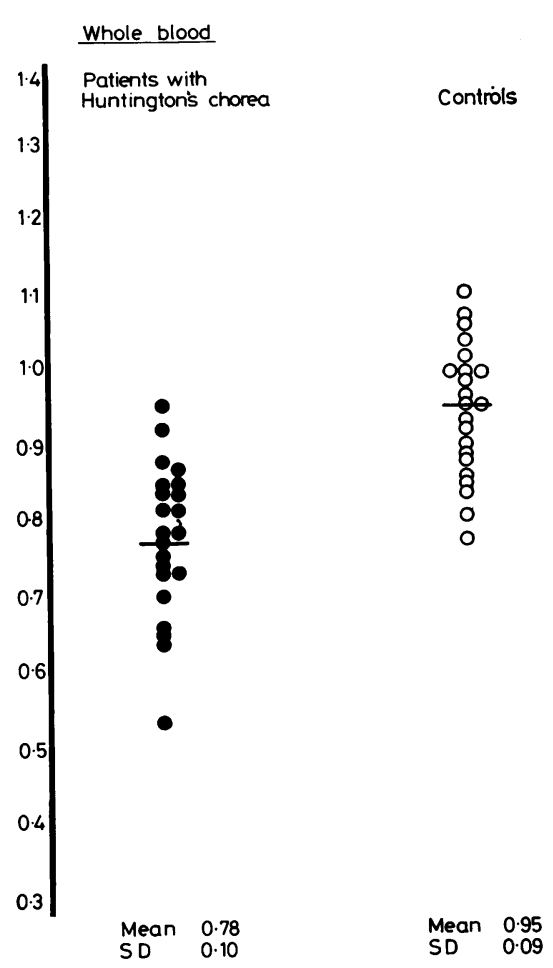

FIG 1 Comparison of cell viability ratios for whole blood cultures derived from patients with Huntington's chorea and from normal age matched controls. 


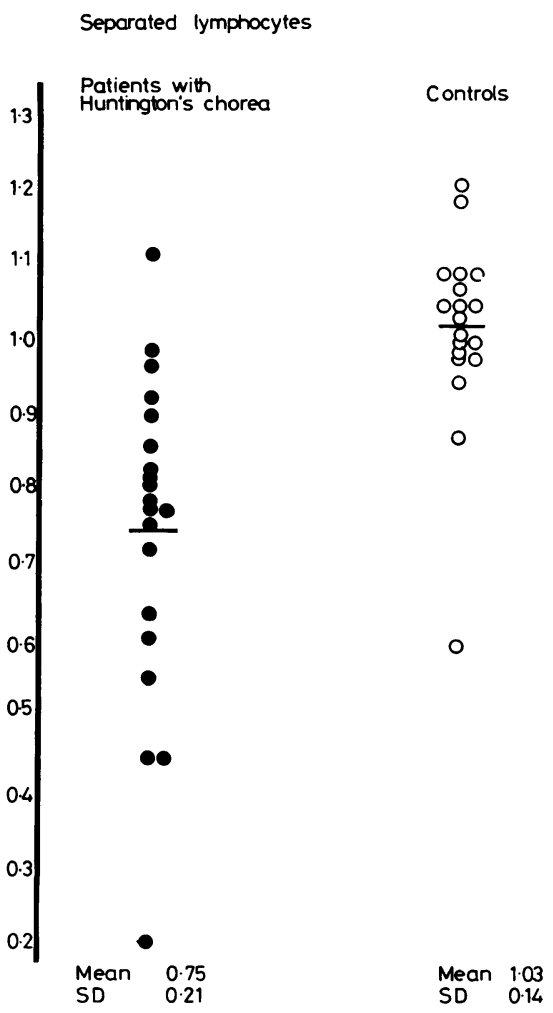

FIG 2 Comparison of cell viability ratios for separated lymphocyte cultures derived from patients with Huntington's chorea and normal age matched controls.

that the drugs most commonly used to treat the patients do not contribute to the difference between their viability ratios and those of controls.

Fig 4 shows the viability ratios, again both for whole blood cultures and for separated lymphocyte cultures, of cells from 18 patients at risk from five families. Initials have been used to differentiate between the families. The viability ratio from the family member with $\mathrm{HC}$ is shown on the figure for comparison. One member of family $\mathbf{H}$ and three members of family $\mathbf{M}$ have viability ratios which are comparable to those of the affected family member.

As each Huntington's chorea patient was matched to a specific control and blood samples from each were studied within the same experiment it was possible to apply a paired $t$ test to their viability ratios.

When ratios obtained from matched whole blood cultures or from separated lymphocyte cultures were subjected to this test, the Huntington's chorea patients were found to be significantly different to the controls ( $p<0.001$ in both cases).

As the drug controls could not be matched within

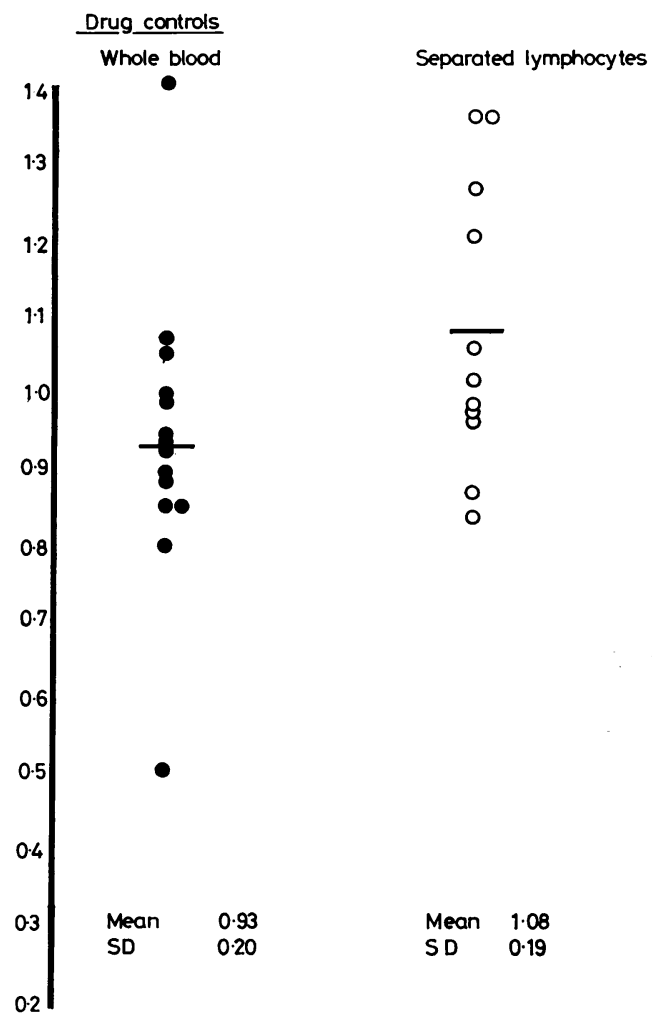

FIG 3 Cell viability ratios for both whole blood and separated lymphocyte cultures derived from patients with schizophrenia who are being treated with phenothiazines or benzodiazepines.

each experiment, in table 2 a different statistical method has been applied to the means of each series of viability ratios. In this test the means are compared to determine whether there are any real differences between the populations studied. Such a probability depends upon the number of standard deviations away from zero of any differences in the means of the two populations being compared. Table 2 shows that the viability ratios of the patients with $\mathrm{HC}$ are different from both those of the matched controls and the drug controls, but that the matched and drug control populations are not statistically different from each other. This is true both for whole blood cultures and separated lymphocytes.

Several variations in timing and conditions were tried in an attempt to improve the rather small differences detected between control subjects and patients with HC. These variations included the use of culture media F10 and 199 instead of RPM1, irradiating the cultures after 0,48 , or 72 hours instead of 24 , and measuring the viability ratios 
At risk tamily members Whole blood

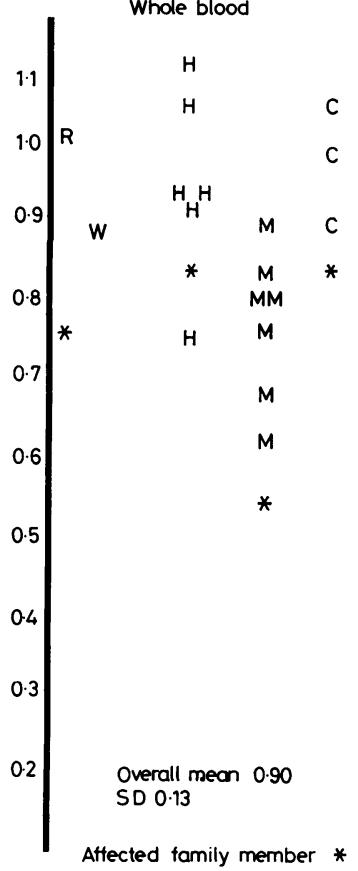

Separated lymphocytes

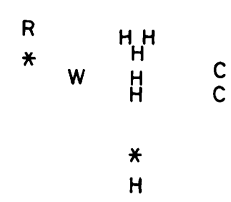

FIG 4 Cell viability ratios for both whole blood and separated lymphocyte cultures derived from patients at risk for Huntington's chorea.

after 24, 48, and 96 hours instead of 72 . None of these variations in experimental procedure was found to improve upon the data presented. When different doses of $\mathrm{X}$ irradiation were employed, however, it can be seen from table 3 that maximal differences between control subject and $\mathrm{HC}$ patients occurred at 100 or 200 rads. Differences were not detected at 50 or 400 rads. In order to estimate experimental reliability, samples from patients and controls were repeated both in and between experiments. The between experiment reproducibility of the method was low (table 4) but this does not affect the results shown in figs 1 and 2 since controls and patients were paired in each experiment

Control subject JR, who merely happened to be a neighbour to one of us, had low viability ratios both for cells from whole blood $(0 \cdot 85)$ and separated lymphocyte $(0.60)$ cultures. When JR's 15 -year-old son was tested, he too had a low viability ratio of 0.82 for whole blood.

One other patient participated in the test series. Although she fulfilled three of the criteria for

TABLE 3 Effect of different $x$-ray doses on cell viability ratios for whole blood cultures derived from different subjects

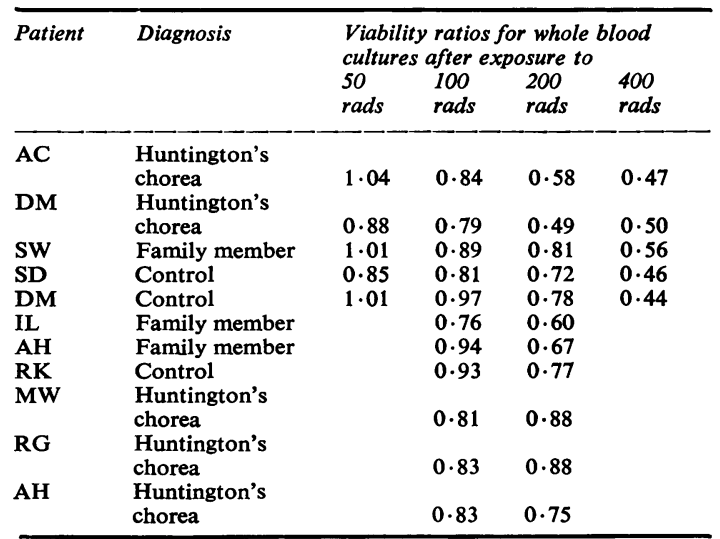

TABLE 4 Degree of reproducibility of the viability ratios in experiments performed on different occasions

\begin{tabular}{|c|c|c|c|c|c|c|c|}
\hline \multirow[t]{2}{*}{ Patient } & \multirow[t]{2}{*}{ Diagnosis } & \multicolumn{6}{|c|}{ Viability ratios } \\
\hline & & $\begin{array}{l}\text { Whole } \\
\text { cultur }\end{array}$ & blood & & $\begin{array}{l}\text { Separ } \\
\text { lymph }\end{array}$ & $\begin{array}{l}\text { ated } \\
\text { ocytes }\end{array}$ & \\
\hline MW & $\begin{array}{l}\text { Huntington's } \\
\text { chorea }\end{array}$ & 0.75 & 0.81 & 0.92 & 0.81 & $0 \cdot 70$ & 0.79 \\
\hline $\mathbf{R G}$ & $\begin{array}{l}\text { Huntington's } \\
\text { chorea }\end{array}$ & 0.95 & 0.83 & & 0.81 & 0.92 & \\
\hline $\mathbf{A H}$ & $\begin{array}{l}\text { Huntington's } \\
\text { chorea }\end{array}$ & 0.73 & 0.83 & & 0.86 & 0.78 & \\
\hline $\begin{array}{l}\text { AC } \\
\text { TW }\end{array}$ & $\begin{array}{l}\text { Huntington's } \\
\text { chorea } \\
\text { Control }\end{array}$ & $\begin{array}{l}0.86 \\
1.06\end{array}$ & $\begin{array}{l}0.84 \\
0.92\end{array}$ & & $1 \cdot 1$ & 0.79 & \\
\hline
\end{tabular}

TABLE 2 Statistical comparison of means of viability ratios of cells from $\mathrm{HC}$ patients and controls

\begin{tabular}{|c|c|c|c|c|c|}
\hline & Difference between means & Variance & $S D$ & $\begin{array}{l}\text { No of } S D \text { away } \\
\text { from zero }\end{array}$ & $p$ \\
\hline \multicolumn{6}{|l|}{ Whole blood cultures } \\
\hline $\begin{array}{l}\text { Patients with Huntington's chorea } \\
\text { vs matched controls }\end{array}$ & $0 \cdot 17$ & $8 \cdot 17 \times 10^{-4}$ & 0.029 & $5 \cdot 95$ & $<0.001$ \\
\hline Patients vs drug controls & $0 \cdot 15$ & $3 \cdot 21 \times 10^{-3}$ & 0.057 & $2 \cdot 6$ & 0.01 \\
\hline Matched controls vs drug controls & 0.02 & $3.06 \times 10^{-3}$ & 0.055 & 0.36 & $>0 \cdot 1$ \\
\hline \multicolumn{6}{|l|}{ Separated lymphocyte cultures } \\
\hline vs matched controls & 0.28 & $3 \cdot 26 \times 10^{-3}$ & 0.057 & $4 \cdot 9$ & $<0.001$ \\
\hline Patients vs drug controls & 0.33 & $5 \cdot 57 \times 10^{-3}$ & 0.075 & $4 \cdot 4$ & $<0.001$ \\
\hline Matched controls vs drug controls & 0.05 & $4.22 \times 10^{-3}$ & 0.065 & $0 \cdot 76$ & $>0 \cdot 1$ \\
\hline
\end{tabular}


Huntington's chorea, she had no choreic movements, being diagnosed as having the rigid form of the disease. The viability ratios calculated for her cells were 0.81 for whole blood culture and 0.78 for separated lymphocytes, respectively.

\section{Discussion}

In this study lymphocytes of patients with $\mathrm{HC}$ have been shown to be more sensitive to $x$-rays than those derived from healthy matched controls, both in whole blood and in separated lymphocyte cultures. The viability ratios of the lymphocytes of a group of HC patients have been found to be lower than those of a group of healthy controls and there is no evidence that this is because of the most common types of drug used to treat these patients. However, although the differences are statistically significant within the groups there is overlap of scores, and also considerable experimental variation.

Despite the fact that the group of first degree relatives at risk have a mean viability ratio which lies between that of the disease and control groups both for whole blood and separated lymphocyte cultures (figs 1, 2, and 4) the variance across the group was no greater than for the other two groups. For this reason the test as it stands cannot be employed diagnostically.

However, when lymphoblastoid lines were studied by Moshell et al, ${ }^{3}$ they found those derived from HC patients to have significantly lower viability ratios after exposure to 100 rads of $x$-rays than those derived from control patients. They also showed no overlap although the numbers employed were small. The present group of patients may well have shown clearer differences if such lines had been analysed, but so far this has not been possible because of technical difficulties in the production of the lines. The great number of drugs used to treat patients makes the rigid elimination of drug effects very difficult. Similarly, although patients with functional mental illness can be selected as controls in such a study, they are not truly representative of the normal population. Despite these difficulties it was found that neither the benzodiazepine nor the phenothiazine groups of drugs significantly altered the sensitivity of lymphocytes to ionising radiation.

Do a proportion of relatives at risk share the abnormal sensitivity, and is lymphocyte hypersensitivity to $X$ irradiation diagnostic for the presence of the HC gene? Three families and two isolated patients at risk were studied.

Family $\mathbf{H}$ included six first degree relatives who ranged in age from 38 to 57 . Their risk for developing the condition was decreased therefore from the original $50 \%$. For that group of six it can be calcu- lated as 1.4 , that is, between one and two persons would be expected to develop HC. In families $M$ and $\mathrm{C}$, consisting of children or young adults whose ages ranged from 8 years to 24 years, one of whose parents had the disease, the risk was $50 \%$, so one would expect three or four of family $\mathbf{M}$ and one or two of family $\mathrm{C}$ to develop the condition. Although the variation in viability ratio of the relatives at risk is no greater than that of controls, if follow-ups were carried out and only those relatives with the low scores developed HC it would be extremely important. From the statistical evidence presented here there is little support for the use of the test as a predictive one. However, it is interesting that since the investigation was carried out, we have learned that family member IL, who had the lowest score in family $\mathrm{H}$ both for whole blood and separated lymphocyte cultures (fig 4), was previously suspected by her general practitioner to be suffering from Huntington's chorea. We were unaware of this at the time we visited her, and she entered the study as a family member at risk. She was both tearful and forgetful and has since developed involuntary movements and dysarthria. The index patient for family $\mathrm{H}$ is MW (table 1 ).

It is not really surprising that some control subjects have been detected who have viability ratios which indicate that their lymphocytes are hypersensitive to ionising radiation. Although syndromes with defective DNA repair, such as AT, are extremely rare, heterozygotes, whose cells may also manifest a degree of increased sensitivity to ionising radiation ${ }^{19}$ are far less rare. Carriers of the AT gene may represent as many as 1 in 100 of the population and collectively heterozygous subjects for this and other similar syndromes must be even more common.

We would like to thank all the consultant psychiatrists in the West Midlands who have so kindly allowed us access to their patients, and also the families of these patients for allowing us to study them.

\section{References}

1 Wendt GG. Das Erkrankungsalter bei der Huntingtonschen. Acta Genet Stat Med 1959;9:18-32.

2 Bruyn GW, Bots GTAM, Dom R. Huntington's chorea: current neuropathological status. Adv Neurol 1979;23: 83-93.

3 Moshell AN, Barrett SF, Tarone RE, Robbins JH. Radiosensitivity in Huntington's disease: implications for pathogenesis and presymptomatic diagnosis. Lancet 1980; i: $9-11$.

4 Robbins JH, Kraemer KH, Lutzner MA, Festoff BW, Coon HG. Xeroderma pigmentosum. An inherited disease with sun sensitivity, multiple cutaneous neoplasms 
and abnormal DNA repair. Ann Intern Med 1974;80: 221-48.

5 Taylor AMR, Harnden DG, Arlett CF, et al. Ataxia telangiectasia: a human mutation with abnormal radiation sensitivity. Nature 1975:248:427-9.

- Propert DN. Presymptomatic detection of Huntington's disease. Med J Aust 1980;1:609-12.

7 Butterfield DA, Oeswein JQ, Markesbery WR. Electron spin resonance study of membrane protein alterations in erythrocytes in Huntington's disease. Nature 1977;267: 453-5.

8 Kirk D, Parrington JM, Corney G, Bolt JMW. Anomalous cellular proliferation in vitro associated with Huntington's disease. Hum Genet 1977;36:143-54.

- Barkley DS, Hardiwidjaya S, Menkes JH. Huntington's disease. Delayed hypersensitivity in vitro to human central nervous system antigens. Science 1977;195:314-6.

10 Barr AN, Heinze WJ, Dobben GD, Valuassori GD, Sugar O. Bicaudate index in computerised axial tomography of Huntington's disease and cerebral atrophy. Neurology 1978;28:1196-200.

11 Manyam NVB, Hare TA, Katz L, Glazer BS, Huntington's disease. Cerebrospinal fluid GABA levels in at risk individuals. Arch Neurol 1978;35:728-30.

12 Patterson RM, Bagchi BK, Test A. The prediction of Huntington's chorea. An electroencephalographic and genetic study. Am J Psychiatry 1948;104:786-97.

13 Chandler JH. EEG in prediction of Huntington's chorea.
An eighteen year follow up. Electroencephalogr Clin $\stackrel{\mathbb{D}}{\vec{D}}$ Neurophysiol 1966;21:79-80.

14 Klawans HL, Paulson GW, Ringel SP, Barbeau A. Use of L-dopa in the detection of presymptomatic Huntington's chorea. $N$ Engl J Med 1972;286:1332-4.

${ }^{15}$ Brackenridge CJ, Case J, Chiu E, Propert DN, Teltscher $B$, Wallace DC. A linkage study of the loci for Huntington's disease and some common polymorphic markers. Ann Hum Genet 1978;42:203-11.

16 Volkers WS, Went LN, Vegter-van der Vlis M, Harper PS, Caro A. Genetic linkage studies in Huntington's chorea. Ann Hum Genet 1980;44:75-9.

17 Arlett CF, Muriel WJ. Radiosensitivity in Huntington's chorea cell strains: a possible preclinical diagnosis. Heredity $1979 ; 42: 276$.

18 Arlett CF. Presymptomatic diagnosis of Huntington's disease? Lancet $1980 ; \mathrm{i}: 540$.

19 Paterson MC, Anderson AK, Smith BP, Smith PJ. Enhanced radiosensitivity of cultured fibroblasts from $\overrightarrow{0}$ ataxia telangiectasia heterozygotes manifested by defec- $\omega$ tive colony-forming ability and reduced DNA repair replication after hypoxic $\gamma$-irradiation. Cancer Res 1979; 39:3725-34.

Requests for reprints to Dr T Webb, Department of Clinical Genetics, Infant Development Unit, Birmingham Maternity Hospital, Birmingham B15 2TG. 